\title{
Efektivitas Model CIRC dan GGE Terhadap Kemampuan Berpikir Kreatif Matematika
}

\author{
Ariyanti Prawitaningrum ${ }^{1 *}$, Endang Endarini $^{2}$ \\ ${ }^{123} J u r u s a n$ Pendidikan Guru Sekolah Dasar, Universitas Kristen Satya Wacana
}

\section{ARTICLEINFO}

Article history:

Received 18 May 2019

Received in revised form 30 June 2019

Accepted 15 July 2019

Available online 25 August 2019

\section{Kata Kunci:}

CIRC, GGE, Kemampuan

Berfikir Kreatif, Matematika

Keywords:

CIRC, GGE, Creative

Thinking Ability,

Mathematics

\begin{abstract}
A B S T R A K
Penelitian ini bertujuan mengetahui ada tidaknya perbedaan efektivitas antara Model CIRC dan GGE Terhadap Kemampuan Berpikir Kreatif Pada Mata Pelajaran Matematika Siswa Kelas IV SD. Penelitian ini termasuk penelitian eksperimen semu. Uji prasyarat menunjukan kedua kelompok homogen dan berdistribusi normal. Uji T menggunakan uji $t$ Independent Sample Test menunjukan t hitung $>t$ tabel yaitu 4,836 $>1,312$ dan signifikan $0,010<0,05$ yang berarti $\mathrm{H}_{0}$ ditolak dan $\mathrm{H}_{1}$ diterima. Hal ini menunjukan adanya perbedaan efektivitas yang signifikan. Selanjutnya dilakukan uji normalitas gain yang menunjukan bahwa model GGE lebih efektif dibanding model CIRC terhadap kemampuan pemecahan masalah matematika.
\end{abstract}

\section{A B S T RA C T}

This study aimed to determine whether there is a difference in effectiveness between the CIRC and GGE Models of Creative Thinking Ability in Mathematics Subjects for fourth grade Elementary Students. This research was a quasi experimental study. The prerequisite tests showed that both groups were homogeneous and have normal distribution. Independent $t$ test Sample showed $t$ arithmetic $>t$ table that is 4,836>1,312 and significant $0.010<0.05$ which means that $\mathrm{H} 0$ is rejected and $\mathrm{H} 1$ is accepted. This shows a significant difference in effectiveness. Normality test showed that the GGE model is more effective than the CIRC model for the ability to solve mathematical problems. 


\section{Pendahuluan}

Pendidikan merupakan suatu hal yang penting dilaksanakan sebagai sarana pembelajaran akademik maupun sebagai perubahan sikap. Proses belajar mengajar yang menjadi inti kegiatan pendidikan di sekolah mempunyai beberapa tujuan, dan tujuan utama yang diharapkan dalam proses pembelajaran adalah perubahan tingkah laku dalam ranah kognitif, afektif, dan psikomotorik. Pembangunan dibidang pendidikan adalah upaya mengembangkan kemampuan dan membentuk watak serta peradaban bangsa yang bermartabat dalam rangka mencerdaskan kehidupan bangsa, bertujuan untuk berkembangnya potensi peserta didik agar menjadi manusia yang beriman dan bertakwa kepada Tuhan Yang Maha Esa, berakhlak mulia, sehat, berilmu, kreatif, mandiri dan menjadi warga negara yang demokratis serta bertanggung jawab (Depdiknas, UU No. 20 Th. 2003: pasal 3). Selain itu, tujuan pendidikan juga menghendaki agar dapat mengembangkan potensi peserta didik menjadi manusia yang aktif di dalam pembelajaran. Karena, sukses tidaknya pembelajaran yang dilaksanakan oleh guru bergantung pada perubahan sikap, tingkah laku, dan pola pikir siswa. Oleh karena itu, tujuan pembelajaran sangat penting dalam men-sukses-kan pendidikan di Indonesia, salah satunya adalah pendidikan di bangku Sekolah Dasar (SD).

Matematika pada dasarnya merupakan salah satu cabang ilmu yang berkaitan dengan penalaran. Objek dasar yang dipelajari matematika adalah abstrak, sering juga disebut objek mental. Objek abstrak tersebut meliputi fakta, konsep, operasi dan prinsip abstrak (Soedjadi, 2000: 13). Objek abstrak inilah yang menyebabkan siswa kesulitan berpikir dalam mempelajari matematika sehingga hal ini berpengaruh pada hasil belajar siswa. Dalam hal ini tugas guru adalah memfasilitasi siswa untuk mewujudkan proses belajar matematika secara lebih konkret, sehingga siswa lebih mudah memahaminya.

Berdasarkan latar belakang yang diuraikan dapat dirumuskan permasalahan dalam penelitian ini yaitu sebagai berikut "Apakah terdapat perbedaan efektivitas antara Model Pembelajaran CIRC dan Model Pembelajaran Group To Group Exchange terhadap Kemampuan Berpikir Kreatif Pada Mata Pelajaran Matematika Siswa Kelas IV SD ?"

Kemampuan berpikir kreatif tidak bisa muncul dengan sendirinya melainkan butuh suatu latihan. Dalam hal ini guru harus bisa melatih dan mengasah kemampuan berpikir kreatif siswa dengan pembelajaran yang memunculkan permasalahan-permasalahan sehari-hari yang bersifat tidak rutin. Masalah rutin adalah masalah yang prosedur penyelesaiannya sekedar mengulang. Sedangkan masalah tidak rutin adalah masalah yang prosedur penyelesaiannya memerlukan perencanaan penyelesaian, tidak sekedar menggunakan rumus dan teori.

Dalam pembelajaran $C I R C$, pembentukan kelompok dipilih secara heterogen, yang berarti dalam satu kelompok terdapat siswa dengan kemampuan yang berbeda.Tidak semua anggota terdiri dari siswa yang pintar maupun kurang pintar, namun dalam satu kelompok terdiri atas siswa yang pintar dan siswa yang kurang pintar. Fokus utama kegiatan CIRC adalah membuat penggunaan waktu menjadi lebih efektif. Siswa dikondisikan dalam tim-tim kooperatif yang kemudian dikoordinasikan dengan pengajaran kelompok membaca, supaya memenuhi tujuan lain seperti pemahaman membaca, kosa kata, pembacaan pesan, dan ejaan. Tujuan utama CIRC adalah menggunakan tim-tim kooperatif untuk membantu para siswa mempelajari kemampuan memahami bacaan yang dapat diaplikasikan secara luas (Slavin, 2010: 203).

Suantini (2013) menyatakan, "pembelajaran kooperatif (cooperative learning) adalah belajar secara bersama-sama, saling membantu antara satu dengan yang lainnya dalam belajar, dan memastikan bahwa setiap siswa dalam kelompok mencapai tujuan atau tugas yang telah ditentukan sebelumnya". Model pembelajaran kooperatif yang dimaksud adalah model pembelajaran Cooperative Integrated Reading and Composition (CIRC). Shoimin (2014:51) menyatakan, "Cooperative Integrated Reading and Composition (CIRC) merupakan model pembelajaran khusus mata pelajaran bahasa dalam rangka membaca dan menemukan ide pokok, pokok pikiran, atau tema sebuah wacana". Model pembelajaran Cooperative Integrated Reading and Composition (CIRC) dimana siswa dalam membaca sebuah bacaan atau cerita secara bersungguh-sungguh dan dapat memahami serta menceritakan kembali isi bacaan. Model ini terdiri dari tiga tahapan yang meliputi: tahapan prabaca yang mencakup kelompok membaca dan memperkenalkan bacaan atau cerita yang anak baca, tahap membaca yang mencakup membaca dengan pemahaman, menulis isi bacaan, dan tahap pascabaca mencakup menceritakan kembali isi bacaan.

Adapun langkah-langkah teknis pembelajaran Cooperative Integrated Reading and Composition (CIRC), Kurniasih dan Sani (2015:92) menyatakan, (1) guru menjelaskan tujuan pembelajaran, dan kemudian membentuk kelompok yang anggotanya kurang lebih 4-6 orang siswa secara heterogen; (2) guru memberikan meteri berupa kliping atau membacakan tertentu sesuai dengan topik pembelajaran; (3) siswa bekerjasama saling membacakan dan menemukan ide pokok dan memberi tanggapan wacana atau kliping dan tulisan pada lembar kertas; (4) setelah itu siswa mempersentasikan atau membacakan 
hasil kerja kelompok masing-masing; (5) setelah semua kelompok mendapatkan giliran, maka guru bersama siswa membuat simpulan dari materi yang telah didiskusikan; (6) dan setelah itu guru menutup pelajaran seperti biasanya.

Selain memiliki sintaks yang jelas, model pembelajaran Cooperative Integrated Reading and Composition (CIRC) juga memiliki beberapa kelebihan. Shoimin (2014:54) menyatakan, kelebihan model Cooperative Integrated Reading and Composition (CIRC) adalah: (1) CIRC sangat tepat untuk meningkatkan keterampilan siswa dalam menyelesaikan soal pemecahan masalah; (2) dominasi guru dalam pembelajaran berkurang; (3) siswa termotivasi pada hasil secara teliti karena bekerja dalam kelompok; (4) pada siswa dapat memahami makna soal dan saling mengecek pekerjaan; (5) membantu siswa yang lemah; (6) dapat menyelesaikan soal yang berbentuk pemecahan masalah. Selain itu, model pembelajaran Cooperative Integrated Reading and Composition (CIRC) dapat memberikan sebuah pengalaman bagi siswa, mengasah dan berpikir siswa, memperluas wawasan siswa karena setelah siswa membaca diajarkan siswa untuk dapat menuliskan apa yang telah dipahami dari bacaan tersebut, serta dapat menciptakan suasana pembelajaran yang menarik.

Model Group to Group Exchange atau disebut model pertukaran kelompok belajar ini adalah tugas yang berbeda diberikan kepada kelompok peserta didik yang berbeda. Masing-masing kelompok "mengajar" apa yang telah dipelajari untuk sisa kelas (Baharudin: 2012). Jadi pembelajaran Group to Group Exchange yaitu model belajar dimana tugas yang berbeda diberikan pada kelompok yang berbeda, kemudian masing-masing kelompok 'mengajarkan' apa yang mereka pelajari kepada kelompok yang lain.

Menurut hasil penelitian yang dilakukan Wedayanti (2013) menyatakan bahwa penerapan model pembelajaran Cooperative Integrated Reading and Composition (CIRC) berbantuan media visual dapat meningkatkan hasil belajar bahasa Indonesia siswa. Hal ini sejalan dengan hasil penelitian yang dilakukan oleh Prabawati (2013) yang menyatakan bahwa Model pembelajaran Cooperative Integrated Reading and Composition (CIRC) Berbantuan Media Gambar Berseri dapat diunggulkan dalam rangka meningkatkan kemampuan membaca pemahaman siswa. Hasil yang sama juga ditunjukkan dari hasil penelitian Kartika (2013) yang menyatakan bahwa model pembelajaran CIRC berbasis Jolly Phonics akan mampu meningkatkan kemampuan membaca dan menulis siswa dibandingkan pembelajaran dengan menggunakan model konvensional. Hal ini dikarenakan kedua model pembelajaran memiliki teori, karakteristik, langkah-langkah pembelajaran dan situasi pembelajaran yang berbeda. Model pembelajaran konvensional didasarkan atas teori belajar behavioristik, dimana pembelajarannya hanya berorientasi pada hasil. Kegiatan pembelajarannya berpusat pada guru (teacher centered) yang menyebabkan situasi pembelajaran menjadi pasif. Lain halnya dalam pembelajaran dengan menggunakan model pembelajaran CIRC berbasis Jolly Phonic.

Tulisan ini akan memberikan gambaran bagaimana CIRC dan GGE dilaksanakan dalam pembelajaran matematika serta memberikan gambaran tentang efektifitas kedua model terhadap kemampuan pemecahan masalah matematika siswa kelas IV SD pada materi keliling dan luas bangun datar persegi, persegi panjang, dan segitiga.

\section{Metode}

Jenis penelitian yang dilakukan adalah penelitian eksperimen. Penelitian eksperimental adalah penelitian yang dilakukan dengan mengadakan manipulasi terhadap objek penelitian serta adanya control (Moh. Nazir, 2005:63). Sedangkan Sugiyono (2010: 107) menyatakan bahwa " penelitian eksperimen adalah penelitian yang digunakan untuk mencari pengaruh perlakuan tertentu terhadap yang lain dalam kondisi yang terkendalikan".

Penelitian ini menggunakan jenis penelitian semu atau dikenal dengan eksperimen kuasi (quasi eksperimental research). Pada eksperimen kuasi ini rumusan masalah harus mengandung hubungan kausal atau sebab akibat antarvariabel yang sudah ditemukan pada saat merumuskan latar belakang. Penelitian ini termasuk dalam penelitian uji teori yang sudah ada. Pada eksperimen kuasi ini diperlukan adanya treatment yang biasanya ditujukan kepada kelas eksperimen dan diharapkan treatment ini dapat memberikan hasil yang berbeda, artinya jauh lebih baik dari kelas kontrol (Deni Darmawan, 2013: 51-52).

Tabel 1. Rancangan Randomized posttest only comparation group desain

\begin{tabular}{cccc}
\hline & Kelompok & Treatment & Pascates \\
\hline Acak & A & X1 & 0 \\
Acak & B & X2 & 0 \\
\hline
\end{tabular}


Keterangan:

A : Kelompok eksperimen

B : Kelompok kontrol

X1 : Perlakuan terhadap kelompok eksperimen berupa model pembelajaran kooperatif tipe CIRC

X2 : Perlakuan terhadap kelompok kontrol berupa model pembelajaran kooperatif tipe GGE

$0 \quad$ : Kemampuan berpikir kreatif pada mata pelajaran matematika siswa setelah dikenai perlakuan.

Penelitian ini dilaksanakan di SDN 01 Tegowanu Kulon dan SDN 03 Tegowanu Kulon pada siswa kelas IV. Langkah-langkah dalam penelitian ini adalah memberikan pretest pada kedua kelompok eksperimen, kemudian untuk kelompok eksperimen I diberikan perlakuan dengan model CIRC dan kelompok eksperimen II dengan model GGE. Selanjutnya kedua kelas akan diberikan posttest setelah mendapat perlakuan. Soal posttest digunakan untuk mengetahui ada tidaknya pengaruh dari perlakuan antara model CIRC dan Group to Group Exchange.

Teknik pengumpulan data yang digunakan dalam penelitian untuk mengetahui kemampuan berpikir kreatif matematika siswa kelas 4 yang pertama adalah teknik tes, digunakan untuk mengukur kemampuan siswa setelah proses pembelajaran. Kedua adalah teknik observasi yang digunakan untuk mengetahui jalannya penelitian yang dilakukan serta untuk mengetahui apa yang dilakukan guru dan siswa selama proses kegiatan belajar mengajar berlangsung. Ketiga adalah teknik dokumentasi, digunakan untuk mendapatkan data tentang rencana pelaksanaan pembelajaran, nilai, dan foto-foto selama kegiatan pembelajaran.

Teknik tes meliputi pengumpulan data hasil belajar UAS matematika siswa dan data hasil belajar matematika siswa menggunakan posttest. Nilai UAS siswa digunakan untuk uji homogenitas dan dianggap sebagai hasil belajar matematika siswa sebelum menggunakan model pembelajaran kooperatif CIRC dan GGE, sedangkan hasil posttest akan dianalisis untuk mengetahui efektivitas hasil belajar matematika siswa antara kedua model pembelajaran.

Untuk menganalisis data pada penelitian ini akan digunakan dua uji statistik data yaitu statistik deskriptif dan statistik inferensial. Statistik Deskriptif adalah statistik yang digunakan untuk menganalisis data dengan mendeskripsikan atau menggambarkan data yang telah terkumpul sebagaimana adanya tanpa bermaksud membuat kesimpulan yang berlaku untuk umum atau generalisasi (Sugiyono,2011:147). Pada penelitian ini yang akan dideskripsikan adalah hasil belajar siswa meliputi mean, standar deviasi, nilai tertinggi, dan terendah. Statistik inferensial digunakan untuk menganalisis data sampel dan hasilnya diberlakukan untuk populasi.Tujuan penelitian ini adalah untuk mengetahui efektivitas hasil belajar matematika dari kelompok eksperimen dan kelompok kontrol, maka statistik inferensial yang digunakan pada penelitian ini pengujian dua sampel tidak berhubungan (Independent Sample T Test).

Untuk menggambarkan rata-rata kecenderungan jawaban responden untuk masing-masing variabel, maka perlu dilakukan analisis data deskriptif. Analisis data deskriptif dilakukan untuk mengetahui penafsiran skor tertinggi dan terendah untuk setiap variabel. Teknik analisis data yang digunakan adalah analisis jalur (path analysis). Menurut Sugiyono (2012: 297), analisis jalur adalah analisis untuk melukiskan dan menguji model hubungan antar variabel yang berbentuk sebab akibat (bukan bentuk hubungan interaktif/reciprocal).

\section{Hasil dan Pembahasan}

Data yang diperoleh dalam penelitian ini adalah data posttest dan pretest kemampuan pemecahan masalah matematika. Adapun komparasi hasil pengukuran kemampuan pemecahan masalah tersaji dalam Tabel 2.

Tabel 2. Komparasi Hasil Pengukuran Kemampuan Berpikir Kreatif Siswa

\begin{tabular}{cccc}
\hline \multirow{2}{*}{ Pengukuran } & \multicolumn{2}{c}{ Rata- Rata Skor (mean) } \\
Eksperimen II & Selisih \\
\hline Pretest & 67.82 & 71.92 & 4.10 \\
Posttest & 81.54 & 88.43 & 6.89 \\
\hline
\end{tabular}

Data perolehan kemampuan awal untuk setiap kelas sampel yang diberi model pembelajaran kooperatif tipe $C I R C$ dan GGE dapat dilihat pada Tabel. Hasil analisis data kemampuan awal dari 25 peserta didik yang akan diberi model pembelajaran kooperatif tipe $C I R C$, menghasilkan nilai minimum 52 , 
maksimum 81, rata-rata 67,82, semuanya lebih rendah daripada pencapaian 25 peserta didik yang akan diberi model pembelajaran kooperatif tipe GGE. Selain itu, standar deviasi dari kelas eksperimen I lebih rendah daripada kelas eksperimen II, standar deviasi kelas eksperimen. Meskipun demikian untuk menentukan apakah kedua sampel itu seimbang dalam populasi, maka perlu dilakukan uji inferensial yang mencakup uji statistik.

Data penelitian yang diperoleh selanjutnya dilakukan uji prasyarat yaitu dengan melakukan uji normalitas dan uji homogenitas. Hasil uji normalitas tersaji pada Tabel 3 sedangkan uji homogenitas tersaji pada Tabel 4 .

Tabel 3. Uji Normalitas Kemampuan Awal

\begin{tabular}{llllllll}
\hline & & \multicolumn{3}{c}{ Kolgomorov-Smirnov $^{\text {a }}$} & \multicolumn{2}{c}{ Shapiro-Wilk } \\
\cline { 3 - 8 } Kode & Statistic & df & Sig. & Statistic & df & Sig \\
\hline \multirow{2}{*}{ Nilai_awal } & Nilai Awal Kelas Eksper &, 109 & 25 &, 200 &, 895 & 25 &, 658 \\
\cline { 2 - 8 } & Nilai Awal Kls pemb &, 140 & 25 &, 062 &, 870 & 25 &, 132 \\
\hline
\end{tabular}

*. This is a lower bound of the true significance.

a. Liliefors Significance Correction

Sumber: data penelitian diolah dengan SPSS, 2019

Tabel 4. Hasil Uji Homogenitas Hasil Belajar ketrampilan berpikir kreatif Kemampuan Akhir

\begin{tabular}{lllll}
\hline Levene & Statistic & df1 & df2 & Sig. \\
\hline 2,130 & & 2 & 47 &, 245 \\
\hline \multicolumn{4}{c}{ Sumber: data penelitian diolah dengan SPSS, 2019 }
\end{tabular}

Berdasarkan Tabel 4 tampak bahwa nilai signifikansi dari uji homogenitas antar kelompok eksperimen sebesar 0,245. Nilai signifikansi lebih dari 0,05 sehingga disimpulkan sampel kelas eksperimen berasal dari populasi dengan variansi yang homogen.

\section{Analisis Variansi}

Syarat-syarat melakukan uji Anava yaitu uji normalitas dan uji homogenitas sudah terpenuhi dan menjadi dasar penggunaan uji Anava guna menguji hipotesis penelitian ini. Hasil uji anava dua jalan dengan sel tak sama dapat dilihat pada Tabel 5 sebagai berikut.

Tabel 5. Hasil Uji Analisis Variansi 2 Jalan

\begin{tabular}{llllll}
\hline Source & Гype III Sum of Squares & df & Mean Square & F & Sig. \\
\hline Corrected Model & $3347,631^{\mathrm{a}}$ & 4 & 669,526 & 3,313 &, 010 \\
Intercept & 385757,994 & 1 & 385757,994 & 1602,132 &, 000 \\
Kelas & 4,542 & 1 & 4,542 &, 028 &, 824 \\
Error & 12528,649 & 44 & 202,342 & & \\
Total & 401638,8 & 50 & & & \\
Corrected Total & 15876,279 & 49 & & & \\
\hline
\end{tabular}

a. R Squared $=, 211$ (Adjusted R Squared $=, 147$ )

Sumber: data penelitian diolah dengan SPSS, 2019

Berdasarkan Tabel 5, terlihat bahwa pada pengaruh pemberian model pembelajaran, nilai signifikansinya sebesar 0,824 (lebih dari 0,05). Hal ini berarti tidak terdapat perbedaan rata-rata yang signifikan antara hasil belajar ketrampilan berpikir kreatif antara peserta didik yang diberi model pembelajaran kooperatif tipe CIRC dengan peserta didik yang diberi model pembelajaran kooperatif tipe GGE.

Hasil analisis variansi diperoleh nilai signifikansi sebesar 0,824 (lebih dari 0,05), hal ini berarti tidak terdapat perbedaan rata-rata yang signifikan antara hasil belajar ketrampilan berpikir kreatif peserta didik yang diberi model pembelajaran kooperatif tipe CIRC dengan peserta didik yang diberi model pembelajaran kooperatif tipe GGE. Simpulan ini sesuai dengan hipotesis pada penelitian ini. Hal ini didukung oleh pernyataan Larasati (2017), bahwa pemberian model pembelajaran kooperatif tipe GGE 
dan tipe $C I R C$ tidak menyebabkan perbedaan hasil belajar ketrampilan berpikir kreatif ranah kognitif peserta didik pada kelas kontrol maupun kelas eksperimen. Tidak adanya perbedaan rata-rata ini disebabkan oleh beberapa faktor pengamatan langsung, antara lain kedua model pembelajaran kooperatif yang menuntut peserta didik untuk bertanggung jawab atas materi yang dipelajarinya, serta peserta didik juga dituntut untuk bisa saling membantu teman yang lain dalam mempelajari materi bangun datar. Hal ini selaras dengan keunggulan yang dimiliki oleh kedua model pembelajaran kooperatif, yaitu mendorong tumbuhnya kesadaran individu, meningkatkan hubungan antarmanusia yang heterogen, peserta didik lebih memaknai pembelajaran, serta berani mengungkapkan pendapat melalui diskusi kelompok. Selain itu, adanya penggunaan lembar kerja mengenai materi bangun datar, menuntut peserta didik untuk berpikir lebih jauh, sehingga peserta didik dapat mencapai taraf penalaran tingkat tinggi.

Hipotesis kedua, hasil analisis variansi dengan tingkat signifikan 5\% diperoleh nilai signifikan sebesar 0,010 (kurang dari 0,05) sehingga $\mathrm{H}_{0}$ ditolak yang berarti ada perbedaan ketrampilan berpikir kreatif yang signifikan diantara tingkatan ketrampilan berpikir kreatif tinggi, sedang dan rendah. Hasil komparasi ganda untuk ketrampilan berpikir kreatif dengan tingkat tinggi dengan sedang diperoleh nilai signifikansi 0,56 (lebih dari 0,05) yang artinya tidak terdapat perbedaan yang signifikan pada kedua kelompok sampel. Hal ini disebabkan oleh peserta didik dengan tingkat kemampuan berpikir kreatif tinggi dan sedang memiliki sikap serius dalam mempelajari materi bangun datar, peserta didik juga tidak segan untuk bertanya pada teman yang lebih memahami materi. Hal ini selaras dengan karakteristik peserta didik dengan tingkat kemampuan berpikir kreatif tinggi dan sedang, yaitu memiliki inisiatif dan motivasi dalam belajar, selain itu peserta didik memiliki keinginan untuk belajar dan memiliki rasa percaya diri. ketrampilan berpikir kreatif dengan tingkat kemampuan berpikir kreatif sedang dengan rendah diperoleh nilai signifikansi 0,578 (lebih dari 0,05). Hal tersebut berarti bahwa tidak terdapat perbedaan rata-rata ketrampilan berpikir kreatif yang signifikan pada kedua kelompok sampel. Berdasarkan pengamatan langsung ketika pelaksanaan penelitian, peserta didik dengan kemampuan berpikir kreatif sedang dan rendah memperhatikan materi bangun datar, namun ada perbedaan sikap kreativitas belajar, yaitu peserta didik dengan kemampuan berpikir kreatif sedang bersungguh-sungguh dalam memahami materi walaupun agak kesulitan, sedangkan peserta didik dengan kemampuan berpikir kreatif rendah hanya melihat materi tersebut dan kurang bersungguh-sungguh dalam memahami materi, namun masih memiliki tanggungjawab untuk mengikuti proses pembelajaran dan mengisi lembar kerja. Hal ini selaras dengan kesamaan karakteristik peserta didik dengan tingkat ketrampilan berpikir kreatif sedang dan rendah, yaitu memandang masalah sebagai hambatan dan belum bisa mengatur kecepatan belajar yang tepat. Berbeda dengan hasil belajar peserta didik dengan tingkat ketrampilan berpikir kreatif tinggi dengan rendah diperoleh nilai signifikansi 0,012 (kurang dari 0,05) yang berarti bahwa terdapat perbedaan rata-rata hasil belajar yang signifikan pada kedua kelompok sampel. Dilihat dari rata-rata hasil belajar untuk peserta didik tingkat ketrampilan berpikir kreatif tinggi 81,52 lebih dari rata-rata hasil belajar peserta didik tingkat ketrampilan berpikir kreatif rendah 71,12.

Hipotesis hasil analisis variansi dengan tingkat signifikansi 5\% pada interaksi antara penerapan model pembelajaran kooperatif tipe CIRC dan GGE dengan ketrampilan berpikir kreatif terhadap ketrampilan berpikir kreatif peserta didik diperoleh nilai signifikansi 0,68 (lebih dari 0,05), yang berarti tidak terdapat interaksi antara variabel model pembelajaran kooperatif dengan ketrampilan berpikir kreatif terhadap hasil belajar peserta didik. Tidak adanya interaksi tersebut, dapat disebabkan karena peserta didik dengan ketrampilan berpikir kreatif dan memahami materi yang diberikan, sedangkan pada peserta didik yang memiliki tingkat ketrampilan berpikir kreatif sedang jika diberi model pembelajaran kooperatif akan sedikit kesulitan mengikuti namun tetap berusaha mempelajari dan memahami materi yang diberikan. Berbeda dengan peserta didik yang memiliki tingkat berpikir kreatif rendah jika diberi model pembelajaran kooperatif apapun akan kesulitan mengikuti proses pembelajarannya, sehingga akan kesulitan mempelajari dan memahami materi, hal itu menyebabkan peserta didik yang memiliki tingkat ketrampilan berpikir kreatif rendah hanya sekadar ikut melihat proses belajar namun tidak memahami dan memaknai proses pembelajaran dari awal sampai akhir.

\section{Simpulan dan Saran}

Berdasarkan hasil penelitian dan pembahasan dapat disimpulkan bahwa terdapat perbedaan kemampuan berpikir kreatif matematika yang signifikan antara Penggunaan Model Pembelajaran CIRC dengan GGE Pada Materi Bangun Datar Siswa Kelas IV SD di Tegowanu Kabupaten Grobogan Semester II Tahun Pelajaran 2018/2019. Hal tersebut didukung dengan adanya hasil penelitian yang menunjukkan bahwa dengan menggunakan uji-t pada hasil posttest kelompok eksperimen 1 dan posttest kelompok eksperimen $2, \mathrm{H}_{0}$ ditolak dan $\mathrm{H}_{1}$ diterima.. Selain itu dengan melihat analisis deskriptif nilai rata-rata 
kedua kelompok yang memiliki selisih 4,10, di mana kelompok eksperimen II (SD Negeri 3 Tegowanu yang pengajarannya menggunakan model $G G E$ ) nilai rata-ratanya adalah 88,43 jauh lebih tinggi dari kelompok eksperimen 1 (SD Negeri 1 Tegowanu yang pengajarannya menggunakan model CIRC).

Berdasarkan penelitian yang telah dilakukan, diperoleh kemampuan berpikir kreatif pada siswa yang diajar dengan menggunakan model pembelajaran GGE lebih tinggi daripada hasil kemampuan berpikir kreatif siswa yang diajar dengan menggunakan model pembelajaran tipe $C I R C$, oleh karena itu penelitian ini memberikan masukan bagi:

1. Bagi Sekolah

a. Sekolah diharapkan dapat meningkatkan kualitas pembelajaran yang lebih baik dengan mengemas suatu pembelajaran yang menyenangkan dan dapat mengaktifkan siswa melalui penggunaan berbagai model pembelajaran kooperatif agar hasil belajar siswa menjadi meningkat.

b. Setelah menggunakan model pembelajaran kooperatif, sekolah diharapkan dapat bersaing di tingkat daerah maupun nasional.

c. Sekolah diharapkan dapat meningkatkan kemajuan pada diri guru dengan meminta guru untuk kreatif dan inovatif dalam menciptakan sebuah pembelajaran yang menarik.

2. Bagi Guru

a. Guru diharapkan untuk mengunakan model pembelajaran GGE dalam pembelajaran matematika, karena sudah terbukti bahwa model pembelajaran kooperatif tipe GGE ini memberikan dampak yang positif terhadap kemampuan berpikir kreatif matematika siswa.

b. Guru diharapkan dapat menggunakan model-model pembelajaran kooperatif yang lain dengan tujuan untuk membuat siswa aktif dan antusias dalam kegiatan belajar mengajar

3. Bagi Siswa

a. Diharapkan dengan menggunakan model pembelajaran GGE dalam pembelajaran matematika, siswa dapat terlibat aktif dan antusias dalam proses pembelajaran.

b. Siswa diharapkan selalu bersemangat dan berpartisipasi aktif apabila guru menggunakan model pembelajaran kooperatif lainnya ketika memberikan pembelajaran dengan mata pelajaran yang berbeda.

c. Siswa harus belajar menerima kelebihan dan kekurangan anggota kelompoknya, tidak boleh membeda-bedakan antar siswa satu dengan siswa yang lainnya, serta belajar untuk membagi ilmunya kepada anggota kelompok yang memiliki kemampuan dibawah rata-rata.

Ucapan terima kasih yang sebesar-besarnya diberikan kepada Ibu Endang Endarini selaku pembimbing I yang senantiasa memberi bimbingan, nasehat, dan motivasi kepada penulis dengan penuh kesabaran sehingga penelitian ini dapat selesai dengan baik. Terima kasih juga kepada kedua orang tua yang senantisa memberikan dukungan dan doa. Tidak lupa kepada teman-teman yang tidak dapat penulis sebutkan satu-persatu yang sudah memberikan dukungan dan semangat sehingga penulis dapat menyelesaikan penelitian ini dengan baik.

\section{Daftar Rujukan}

Baharudin, 2012. Kepemimpinan Pendidikan Islam.Yogyakarta: Ar-Ruz Media.

Depdiknas. 2003. UU No. 20 Th. 2003. Jakarta: Departemen Pendidikan Nasional.

Kartika Istri. 2013. Pengaruh Model Pembelajaran CIRC Berbasis Jolly Phonics Terhadap Kemampuan Membaca dan Menulis Siswa Kelas II SD Gugus II Kecamatan Sukawati MIMBAR PGSD Undiksha Vol1, No 1 (2013).

Kurniasih dan Sani. 2015. Ragam pengembangan model pembelajaran. Jakarta: Kata Pena

Nazir, Moh. 2005. Metode penelitian. Bogor : Ghalia Indonesia.

Prabawati Chandra. 2013. Pengaruh Model Circ Berbantuan Media Gambar Berseri Terhadap Kemampuan Membaca Pemahaman pada Siswa Kelas V SD Gugus IV Kecamatan Rendang. MIMBAR PGSD Undiksha Vol1, No 1 (2013).

Shoimin, Aris. 2014. Model pembelajaran inovatif dalam kurikulum 2013. Yogyakarta: AR-RUZZ MEDIA. 
Slavin, Robert. 2000. Educational Psycology: Theory and Practice. Sixth Edition. Boston: Allyn and Bacon.

Soedjadi, R. 2000. Kiat Pendidikan Matematika di Indonesia. Jakarta: Departemen Pendidikan Nasional

Suantini, Ni L. P. Yuni. 2013. “Pengaruh Model Pembelajaran Kooperatif Tipe CIRC Terhadap Pemahaman Konsep IPA Siswa Kelas IV di Gugus II Kecamatan Gerokgak”. Jurnal. Jurusan PGSD Undiksha

Sugiyono. 2010. Metode Penelitian Pendidikan Pendekatan Kuantitatif, kualitatif, dan R\&D. Bandung: Alfabeta

Wedayanti, Ni Wyn. Anggun. 2013. "pengaruh model pembelajaran CIRC berbantuan gambar berseri terhadap keterampilan membaca dan menulis siswa kelas IV SDN 18 pemecutan". Journal. Jirisan PGSD Undiksha. 